University of Nebraska - Lincoln

DigitalCommons@University of Nebraska - Lincoln

1996

\title{
Long-Term Declines in Nest Success of Prairie Ducks
}

\author{
Wendy D. Beauchamp \\ University of Guelp \\ Rolf R. Koford \\ USGS Northern Prairie Wildlife Research Center \\ Thomas D. Nudds \\ University of Guelp \\ Robert G. Clark \\ USGS Northern Prairie Wildlife Research Center \\ Douglas H. Johnson \\ Northern Prairie Wildlife Research Center, Douglas_H_Johnson@usgs.gov
}

Follow this and additional works at: https://digitalcommons.unl.edu/usgsnpwrc

Part of the Other International and Area Studies Commons

\footnotetext{
Beauchamp, Wendy D.; Koford, Rolf R.; Nudds, Thomas D.; Clark, Robert G.; and Johnson, Douglas H., "Long-Term Declines in Nest Success of Prairie Ducks" (1996). USGS Northern Prairie Wildlife Research Center. 221.

https://digitalcommons.unl.edu/usgsnpwrc/221
}

This Article is brought to you for free and open access by the US Geological Survey at DigitalCommons@University of Nebraska - Lincoln. It has been accepted for inclusion in USGS Northern Prairie Wildlife Research Center by an authorized administrator of DigitalCommons@University of Nebraska - Lincoln. 


\section{LONG-TERM DECLINES IN NEST SUCCESS OF PRAIRIE DUCKS}

WENDY D. BEAUCHAMP, ' Zoology Department, University of Guelph, Guelph, ON N1G 2W1, Canada ROLF R. KOFORD, ${ }^{2}$ National Biological Service, Northern Prairie Wildlife Research Center, Jamestown, ND 58401, USA THOMAS D. NUDDS, Zoology Department, University of Guelph, Guelph, ON N1G 2W1, Canada ROBERT G. CLARK, Canadian Wildlife Service, Prairie and Northern Wildlife Research Center, 115 Perimeter Road, Saskatoon, SK S7N 0X4, Canada

DOUGLAS H. JOHNSON, National Biological Service, Northern Prairie Wildlife Research Center, Jamestown, ND 58401, USA

Abstract: Increased predation on nests of ducks in prairie uplands, as a result of habitat alteration, has been hypothesized to cause decreased nest success and population sizes. We tested whether, and by how much, nest success declined using data compiled from 37 studies conducted between 1935 and 1992 at 67 sites in the Prairie Pothole Region of Canada and the United States. Nest success declined $(P=0.0002)$ over time, but time explained only $10 \%$ of the variation; precipitation $(P=0.79)$ did not account for additional variation in nest success. Nest success declined at similar $(P=0.13)$ rates among 5 species, but late nesters (gadwall [Anas strepera], blue-winged teal $[A$. discors], and northern shoveler [A. clypeata]) had higher success $(P=$ 0.004) than early nesters (mallard [A. platyrhynchos], and northern pintail [A. acuta]). Populations of gadwalls and northern shovelers, however, have not declined, indicating that declines in nest success may not be related causally to population change. Long-term population declines in blue-winged teal, northern pintails, and mallards coincide with large-scale temporal declines in nest success. Declines in nest success were parallel in parkland and grassland regions, suggesting a causal agent (or agents) that act(s) at a broad scale, despite inherent differences in the composition of the predator communities and habitats between regions.

J. WILDL. MANAGE. 60(2):247-257

Key words: conserved soil moisture, habitat fragmentation, long-term data, nest success, population decline, Prairie Pothole Region, upland habitat, waterfowl.

Declines of some duck populations in the Prairie Pothole Region (U.S. Fish and Wildl. Serv. and Can. Wildl. Serv. 1986, Anonymous 1989, Dickson 1989, Caithamer et al. 1992, Bethke and Nudds 1995) have led to speculation about ecological causes and management remedies. Hypothesized causes for the declines include decreased natality because of habitat alteration, drought, farming practices, and depredation of nests, and/or increased mortality from overhunting, environmental contaminants, disease, and predation. Predation has been identified as a principal agent of nest loss (Sargeant and Raveling 1992), and it is thought that nest success has declined because of increased losses to predators caused, ultimately, by intensive agriculture and widespread habitat change (e.g., Boyd 1985, Cowardin et al. 1985, Klett et al. 1988, Johnson et al. 1989).

\footnotetext{
${ }^{1}$ Present address: Wildlife Ecology Research Group, Canadian Wildlife Service, 5421 Robertson Rd., R.R.1, Delta, BC, V4K 3N2, Canada.

${ }^{2}$ Present address: Iowa Cooperative Fish and Wildlife Research Unit, Iowa State University, Ames, IA, 50011 , USA.
}

Although the perception is widespread that nest success in the Prairie Pothole Region is lower now than before, the evidence is drawn from comparisons across different time scales and locales. Hammond and Forward (1956:246), for example, estimated that apparent nest success (the ratio of successful nests to no. of nests found) at a site in North Dakota decreased from 70$80 \%$ to $20-30 \%$ between the periods $1937-38$ and 1947-51. From several studies in the Canadian and American prairies, Miller (1971) concluded that nest success had declined from $63 \%$ (apparent success) in the 1930s to $29 \%$ in the 1950s. Nelson and Duebbert (1973) suggested that nest success had decreased from 60 $80 \%$ (apparent success) in the 1930 s, to $30-40 \%$ in the 1950 s, and speculated that a considerable decline had continued into the 1970s. Klett et al. (1988) however, compared nest success (Mayfield method) from 3 states in the Prairie Pothole Region between 1966 and 1984 and found little evidence of decline. Thus, it is still not clear whether nest success actually has declined since the 1930s and, if it has, to what extent.

A large number of nesting studies were conducted during the 1980s (Greenwood 1986, Johnson et al. 1988a, Greenwood et al. 1990, 


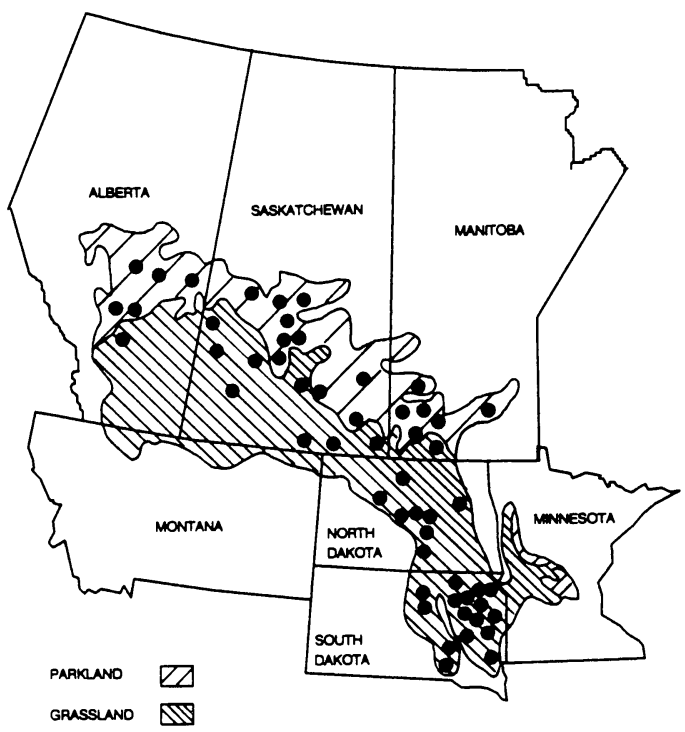

Fig. 1. Locations of study sites used in analyses of nest success of upland-nesting ducks in the Prairie Pothole Region of North America during 1935-92.

Clark et al. 1991) which was one of the driest decades since the 1930s. Long-term variation in nest success is potentially affected by variation in soil moisture conditions in at least 2 ways. First, soil moisture can affect the establishment of vegetation cover, therefore it may affect residual vegetation the following spring when ducks begin to nest. Reduced nest concealment may lead to lower nest success, at least in certain predator communities (Clark and Nudds 1991). Second, nest success of ducks may be positively correlated with small mammal abundance (Byers 1974, Weller 1979) or insects (Crabtree and Wolfe 1988), which may be alternative prey for nest predators. When dry conditions result in lower productivity of primary producers, alternative prey may become scarce and predators may consume a higher proportion of duck eggs (Johnson et al. 1989).

Further, the composition of the nest-predator community varies across the Prairie Pothole Region (Sargeant et al. 1993) and has changed over time (Johnson and Sargeant 1977). Because the effect of nest concealment on nest success differs with composition of the community of nest predators (e.g., avian vs. mammalian; Clark and Nudds 1991), we tested the extent to which temporal and spatial variation in nest success might differ between grassland and aspen parkland.
Using data compiled from published and unpublished studies (1935-92) of upland-nesting ducks in the Prairie Pothole Region, we tested whether nest success (1) declined over time, (2) was related to variation in soil moisture, (3) differed among species, or (4) differed between ecogeographic regions.

We are grateful to G. S. Adams, R. J. Greenwood, A. B. Sargeant, and P. S. Taylor for access to unpublished data and manuscripts; R. W. Bethke for providing some of the conserved soil moisture indices; J. P. Ball for SAS consulting; and D. Hill, H. A. Kantrud, D. M. Lavigne, J. T. Lokemoen, A. B. Sargeant, and an anonymous referee for commenting on earlier drafts. Financial assistance was provided by the Canadian Wildlife Service (CWS), the CWS University Research Support Fund, the Prairie Habitat Joint Venture of the North American Waterfowl Management Plan through CWS and Wildlife Habitat Canada, the Natural Sciences and Engineering Research Council of Canada (Grant A7757), and the U.S. Fish and Wildlife Service.

\section{METHODS \\ Nest Success Data}

We reviewed published and unpublished studies of nest success from parkland and grassland regions in 3 provinces (Alta., Manit., Sask.) and 2 states (N.D. and S.D.; Fig. 1) where longterm data were available for 5 species of uplandnesting ducks: blue-winged teal, gadwall, mallard, northern shoveler, and northern pintail. We included only nonisland sites where it was reported no organized predator control was conducted. (Beauchamp et al. 1996 analyzed nest success on islands and at sites with predator control.)

To ensure comparable point estimates of nest success, in space and time, we excluded studies from our analysis if data had been combined for $>1$ study site or for $\geq 2$ years at 1 site. These 2 criteria resulted respectively in the exclusion of only 7 and 9 nest success estimates. Further, we did not include estimates of nest success based on $<10$ nests. We used 143 point estimates of nest success from 37 sources; the earliest study was conducted in 1935 and the most recent in 1992 (Appendix A).

We created 2 datasets, 1 with estimates of nest success for each species (unpooled) at each site in each year $(n=232$, Appendix A), and 
another with nest success pooled across species at each site in each year $(n=143)$. To test for differences in nest success among species, we analyzed unpooled data. However, multiple estimates of nest success (i.e., from $>1$ species) at a given site in a given year are not likely independent because all species would be subjected to similar environmental conditions. For this reason, we used pooled data in all other analyses to reduce effects of nonindependence. The pooled data is also valuable in that more study sites are represented (67 compared with 49 in the unpooled dataset), because some authors did not report nest success separately for each species.

\section{Transforming Apparent Nest Success Estimates}

One problem in undertaking a temporal analysis is that incomparable estimators of nest success have been used over time. The "apparent" estimator used in older studies is almost always biased high (Mayfield 1961, 1975; Miller and Johnson 1978), but the contemporary Mayfield method more accurately estimates "true" nest success (Mayfield 1961, 1975). Eleven studies (1977-90) that we used in our analyses reported Mayfield estimates (Appendix A). When only apparent nest success was reported, we converted it to Green's (1989) "Mayfield-equivalent" (Appendix A), thereby enabling us to examine long-term variation in nest success. Johnson (1991) reported no directional bias for Green's transformation provided the probability of finding nests did not vary with nesting stage. This equal chance criterion might not be met if a study area was searched frequently and thoroughly. In this situation, nest success would be underestimated because Green's transformation would overcorrect for nest exposure (Johnson 1991). Because early studies lacked the efficiency of the cable-chain drag (Higgins et al. 1969) for nest searching, these sites were likely covered less systematically than those searched later and would not, therefore, violate the assumption of Green's transformation. Thus we considered it reasonable to compare Greentransformed estimates of apparent nest success from earlier studies with Mayfield estimates from later studies.

We treated sites as random samples in the analyses and assumed that all estimates of nest success were equivalent. The problem with the assumption of equivalence is that most nest abandonments were counted as nest failures in the older studies, whereas many recent studies did not use abandoned nests to estimate nest success if the abandonments were thought to have been caused by investigators.

\section{Precipitation Data}

We used conserved soil moisture (CSM) indices, available from other broad-scale studies conducted in the Canadian part of the Prairie Pothole Region (Bethke and Nudds 1993), to estimate yearly and regional variation in climatic conditions. (Similar data for the U.S. portion of our study area were not available.) Conserved soil moisture is a weighted mean of total precipitation in the 21 months preceding 1 May in any given year (Williams and Robertson 1965, Boyd 1981). More weight is given to precipitation in fall and winter because rainfall during the summer growing season does not contribute as much to persistent soil moisture (Boyd 1981). We estimated CSM for each of the 31 Canadian study sites using precipitation data from the nearest weather station(s) (Mon. Rec., Atmos. Environ. Serv., Environ. Can., Ottawa, Ont.) for each year that nest success data were available. For study areas $>50 \mathrm{~km}$ from the nearest weather station, we used mean CSM of the closest 23 stations.

\section{Statistical Analysis}

We conducted linear regression and analysis of covariance (ANCOVA) using the General Linear Model (GLM) procedure of SAS (SAS Inst. Inc. 1985, Freund et al. 1986). Frequency distributions of the residuals from the linear models departed from normality; a $\log _{10}$ transformation best normalized the data and was used in our analyses.

We conducted preliminary analyses to compare the effects of using different combinations of unweighted data, weighting by the number of nests, including studies with 10 to 20 nests, and truncating the dataset at various years (i.e., excluding the 1930s, excluding the 1940s, etc.). We found that our conclusions were robust and that the statistical parameter estimates differed only slightly. Such uniformity was not surprising, because of the large sample size and the large amount of inherent variation in the data. Further, it is difficult to determine a weighting scheme a priori, or to justify one a posteriori. 


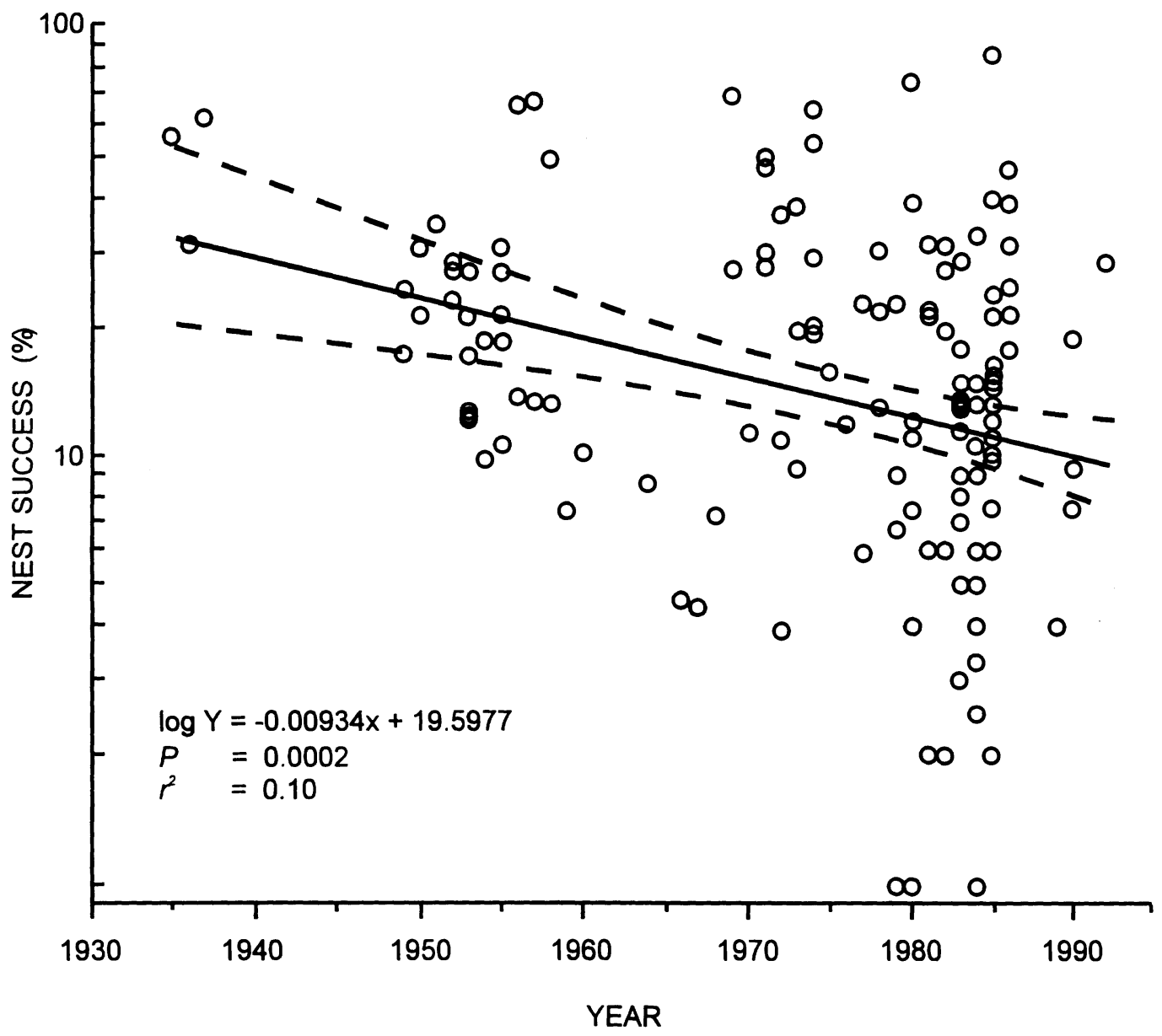

Fig. 2. Decline in nest success of 5 upland-nesting species of ducks (pooled) at 67 study sites in Prairie Pothole Region during 1935-92 $(n=143)$. Predicted nest success $(-)$ and confidence intervals $(--)$ are shown for the regression.

We chose not to weight the data, to increase our sample size by including studies with $\geq 10$ nests, and to include all years for which we could find data.

To test whether nest success declined over time, we regressed pooled nest-success estimates against year. To determine whether precipitation explained additional variation in nest success (after accounting for yr), we conducted a separate regression of nest success on year using only data from Canadian sites for which we had estimates of CSM. We then regressed residuals against CSM. We conducted a full ANCOVA to detect interactions among year, species, and region. If there were none, we conducted separate ANCOVAs to test for differences in nest success among species (using unpooled data) and between regions (using pooled data) (Freund et al.
1986:202-203). Before testing for differences (in intercepts) between species or regions using $\mathrm{AN}$ COVA, we tested the assumption of homogeneity of slopes among groups (Freund et al. 1986: 200-205).

To examine differences among species, we conducted multiple comparisons of least-squares means (Freund et al. 1986), adjusted for year effect, using a Bonferroni adjusted $\alpha=0.01$ per comparison to ensure an overall error rate of $<0.05$.

\section{RESULTS}

Over all sites, nest success declined over time $(F=14.93 ; 1,141 \mathrm{df} ; P=0.0002$; Fig. 2). Year alone, however, accounted for little variation $\left(r^{2}\right.$ $=0.10)$ in nest success . Estimated mean nest 


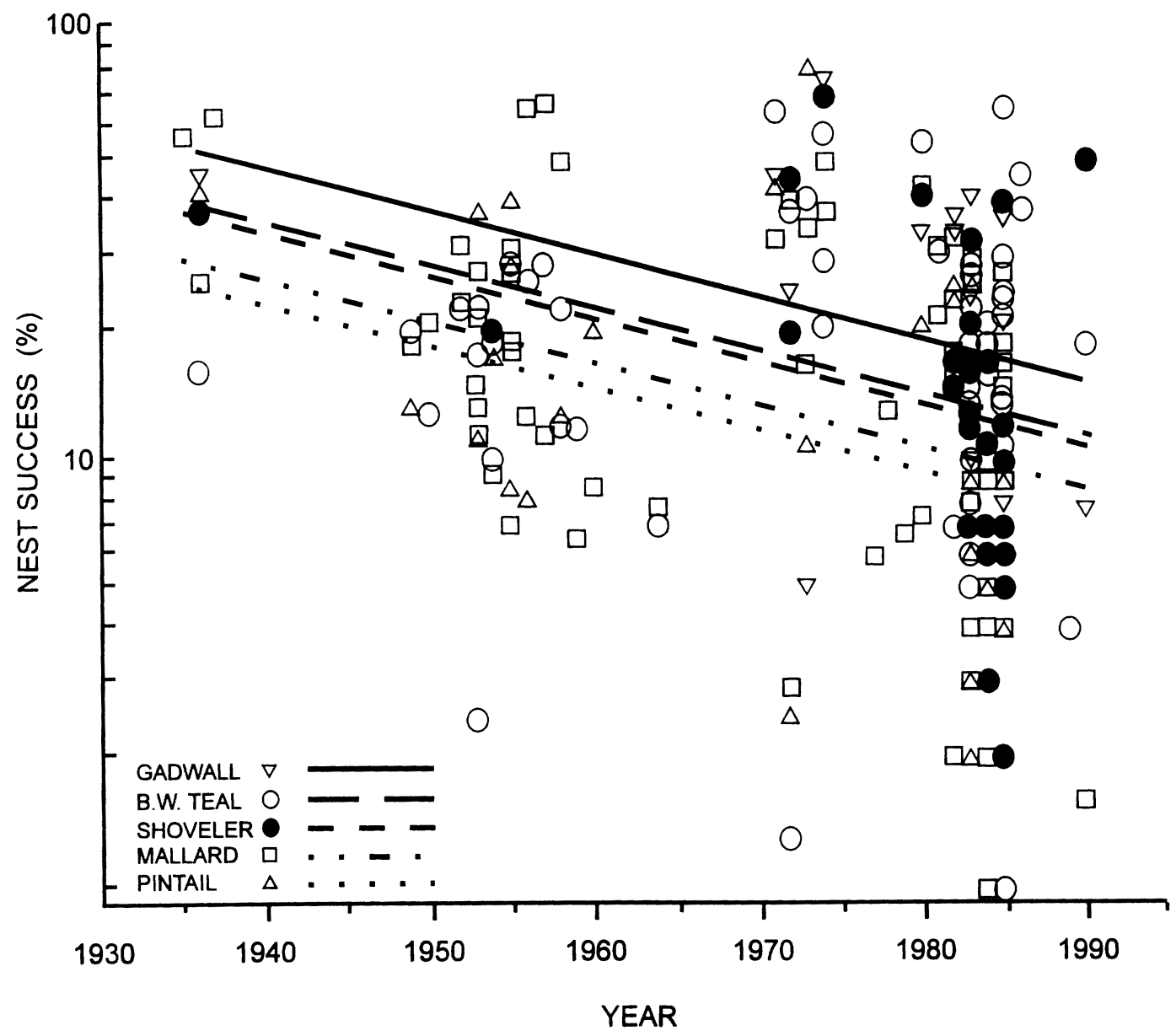

Fig. 3. Decline in nest success for each of 5 upland-nesting duck species at 49 study sites in the Prairie Pothole Region, 193592. Species that nest early (mallards $[n=81]$ and northern pintails $[n=40]$ ) have lower intercepts than those that nest later (northern shovelers $[n=29]$, blue-winged teal $[n=59]$ and gadwalls $[n=23]$ ).

success over all study sites was $33 \%$ (95\% CI 2152 ) in 1935 (the earliest yr in the analysis), $21 \%$ (95\% CI 17-28) in 1955 (the first yr of breedingground population surveys); $15 \%$ (95\% CI 1318) in 1970 (the beginning of a decade with particularly high populations), and 10\% (95\% CI 8-12) in 1992 (the most recent $\mathrm{yr}$ in the analysis).

In Canadian prairie-parkland sites alone, nest success also declined over time $(F=16.88 ; 1,73$ df; $P<0.0001$ ). Analysis of residuals indicated that conserved soil moisture did not explain any additional variation in nest success after variation due to year was taken into account $(F=$ $0.07 ; 1,72 \mathrm{df} ; P=0.79$ ).

The full ANCOVA model indicated that there was no interaction between species and region over time in the unpooled data set $(F=1.37$; $9,212 \mathrm{df} ; P=0.94$ ). Subsequently, ANCOVA models to test for differences among species and between regions were conducted separately (Freund et al. 1986:202-203). Rates of decline in nest success did not differ among species $(F$ $=1.82 ; 4,222 \mathrm{df} ; P=0.13)$, but nest success did $(F=3.68 ; 4,226 \mathrm{df} ; P=0.006)$. Northern pintails and mallards (which did not differ significantly from each other, $P=0.45$ ) had consistently lower nest success $(P=0.004)$ than did northern shovelers, blue-winged teal, and gadwalls (which did not differ significantly from each other, $P$ $=0.18$; Fig. 3). Neither nest success $(F=1.20$; $1,140 \mathrm{df} ; P=0.27)$ nor its rate of decline $(F=$ $0.95 ; 1,139 \mathrm{df} ; P=0.33$ ) differed between grassland $(n=85)$ and parkland $(n=58)$ regions. 


\section{DISCUSSION}

Nest success of upland-nesting ducks in the Prairie Pothole Region declined between 1935 and 1992 . However, year accounts for only $10 \%$ of the variation in nest success, leaving $90 \%$ of the variation unexplained. Kalmbach (1939:601) thought that $63 \%$ ( $42 \%$ Mayfield equivalent) nest success was typical for waterfowl at unmanaged sites "under varied conditions". We estimated that (corrected) nest success in 1935, the earliest year for which we had data, averaged $33 \%$ (95\% CI 21-52). The rate of decline we found was $<0.5 \%$ per year compared with a decline of 2 $4 \%$ per year, inferred from earlier papers (Miller 1971, Nelson and Duebbert 1973). Nest success may never have been as high in the 1930s as has been thought, and the decline appears to be lower than suggested earlier.

Conserved soil moisture correlates positively with duck population sizes (Boyd 1981), but we found no evidence that it was associated with nest success. Perhaps the mechanisms we proposed (effects on residual vegetation or alternative prey) do not affect nest success, or are only weakly linked to CSM. For example, residual spring vegetation may also be affected by snowpack and subnivean harvest by rodents (Higgins and Barker 1982).

Nest success and its rate of decline did not differ between parkland and grassland regions, for all 5 species, despite inherent differences in composition of the predator communities between these regions (Sargeant et al. 1993). This suggests a causal agent (or agents) that act(s) at a large scale and affects all species and areas similarly.

Although the rate of decline was not different among species, average nest success differed. From lowest to highest, the order of adjusted means of nest success was northern pintail, mallard, northern shoveler, blue-winged teal, and gadwall. Interestingly, this ranking correlates with nesting chronology. Nest initiation dates vary among locations and from year to year depending on weather conditions but, in general northern pintails and mallards are early nesters (beginning in early Apr), northern shovelers are intermediate, teal are later (peak clutch initiation in late May), and gadwalls have the latest peak clutch initiation (Jun) of all dabbling ducks (Bellrose 1980). A similar ranking of nest success among dabbling duck species was found by Klett et al. (1988).
Interspecific differences in nest site selection, as well as timing of nest initiation, may account for some differences in nest success among species. Northern pintails tend to nest in open areas more than do other dabbling ducks (Bellrose 1980), and because vegetation is generally sparse in early spring their nests may be more prone to predation due to lack of concealment. Pintails tend also to nest in stubble fields where nest losses to farming practices, especially spring plowing, may be relatively greater than for other dabbling ducks (Milonski 1958, Klett et al. 1988). In our review, however, few studies from which we gleaned data had been done in cropland because most species usually nest in untilled habitats of marginal agricultural value, so we suspect that spring plowing cannot be a general explanation for the pattern of interspecific variation in nest success that we observed. Mallard nests may also be vulnerable to spring plowing (Bellrose 1980, Sugden and Beyersbergen 1985), but mallards generally use dense cover. Gadwalls nest in dense vegetation (Hines and Mitchell 1983), in part because they nest later in the season when vegetation is more fully grown. Dense vegetation may deter movement of some mammalian predators, as Duebbert (1969) speculated, and avian predators may not detect well-concealed nests (Clark and Nudds 1991). Further, there is evidence that some predators feed on duck eggs early in the season and later switch to alternative prey (Crabtree and Wolfe 1988). Therefore, late nests may, in general, be less vulnerable to predation.

There are several inherent limitations to testing hypotheses with historical data, but we think these problems do not seriously diminish our attempt to address the critical question of whether nest success declined over time. If bias exists, we think it might occur principally in the direction of overestimating the decline. First, particularly in the oldest studies, sites may not have been randomly selected and, not truly representative, because nest searches may have been conducted (either intentionally or unintentionally) in the most productive habitats. Second, only studies that found high nest success may have been published earlier. Third, the scarcity of studies of nest success before the 1970s, and the high variability in nest success reported then, may have resulted in a Type I error (i.e., we may have detected a false decline in nest success), though various cleavages of the data at different times do not result in substantially dif- 
ferent conclusions about the temporal variation in nest success. On the other hand, early estimates of nest success, relative to later areas, could underestimate productivity. Nest abandonments were counted as nest failures in older studies, whereas many recent studies did not use abandoned nests if the cause was suspected to be observer-induced. Also, although female success (Cowardin and Johnson 1979) is infrequently reported, it may be a more appropriate index of productivity in some cases. Female success would equal nest success if no renesting occurred. However, female success may be much higher when renesting does occur (Cowardin and Johnson 1979), in which case productivity could be higher than our results indicate, especially in latter years.

\section{MANAGEMENT IMPLICATIONS}

We found evidence that nest success declined between the 1930s and 1992, albeit more slowly than previous estimates, for all 5 species examined. But census data indicate gadwalls and northern shovelers have not shown concurrent population declines, and have actually increased in some areas (Dickson 1989). Together, these observations are inconsistent with the idea that nest success is a principal cause of variation in population size. Management aimed at increasing nest success implicitly assumes that it will lead to increases in fall flight and recruitment to the breeding population. Others have acknowledged that nest success may not be the only, or most important, factor limiting population growth (Cowardin et al. 1985, Clark and Nudds 1991). Accordingly, more attention is being directed to brood survival (Talent et al. 1983, Orthmeyer and Ball 1990, Rotella and Ratti 1992) and survival throughout the annual cycle (Hill 1984, Johnson et al. 1988b, Hestbeck et al. 1989).

The widespread nature of declining nest success implies that a large-scale solution would be required to reverse the trend. In general, it may be more cost-effective to direct efforts toward encouraging extensive management (recovery of marginal farmland, alternative farming practices), rather than intensive, site-specific management (e.g., direct predator control programs). However, in severely altered landscapes, intensive management (however expensive) might be the only way to augment nest success, but this question still needs to be ad- dressed (Clark and Nudds 1991, Nudds and Clark 1992). Whatever decisions are made regarding the management of nest predators in particular circumstances, we advocate its implementation in ways that the effects can be properly evaluated by the most rigorous means possible (Macnab 1983, Clark and Nudds 1991, Clark and Diamond 1993).

\section{LITERATURE CITED}

ANONYMOUS. 1989. Prairie habitat joint venture: North American waterfowl management plan Saskatchewan implementation strategy. Saskatoon, Sask. 2lpp.

Beauchamp, W. D., T. D. Nudds, and R. G. Clark. 1996. Duck nest success declines with and without predator management. J. Wildl. Manage. 60: 258-264.

Bellrose, F. C. 1980. Ducks, geese and swans of North America. Stackpole Books, Harrisburg, Pa. 540pp.

BETHKE, R. W., AND T. D. NudDS. 1993. Variation in the diversity of ducks along a gradient of environmental variability. Oecologia 93:242-250.

- AND - 1995. Effects of climate change and land use on duck abundance in Canadian prairie-parklands. Ecol. Appl. 5:588-600.

BoyD, H. 1981. Prairie dabbling ducks, 1941-1990. Can. Wildl. Serv. Prog. Notes 119. 9pp.

1985. The large-scale impact of agriculture on ducks in the prairie provinces, 1950-1981. Can. Wildl. Serv. Prog. Notes 149. 13pp.

Byers, S. M. 1974. Predator-prey relationships on an Iowa waterfowl nesting area. Trans. North Am. Wildl. Nat. Resour. Conf. 39:223-229.

Caithamer, D. F., G. W. Smith, F. A. Johnson, J. B. Bortner, J. P. Bladen, and P. D. Keywood. 1992. Trends in duck breeding populations, 1955-92. Adm. Rep. 92/07-08. U.S. Fish and Wildl. Serv., Washington, D.C. 24pp.

Clark, R. G. And A. W. Diamond. 1993. Restoring upland habitats in the Canadian prairies: lost opportunity or management by design? Trans. North Am. Wildl. Nat. Resour. Conf. 58:551-564.

— AND T. D. NuDDS. 1991. Habitat patch size and duck nesting success: the crucial experiments have not been performed. Wildl. Soc. Bull. 19: 534-543.

$\longrightarrow$, AND R. O. BAIley. 1991. Populations and nesting success of upland-nesting ducks in relation to cover establishment. Can. Wildl. Serv. Prog. Notes 193. 6pp.

Cowardin, L. M., D. S. Gilmer, and C. W. ShaifFER. 1985. Mallard recruitment in the agricultural environment of North Dakota. Wildl. Monogr. 92. 37pp.

-, AND D. H. Johnson. 1979. Mathematics and mallard management. J. Wildl. Manage. 43: 18-35.

Crabtree, R. L., and M. L. Wolfe. 1988. Effects of alternate prey on skunk predation of waterfowl nests. Wildl. Soc. Bull. 16:163-169.

DiCKSON, K. M. 1989. Trends in sizes of breeding 
duck populations in Western Canada, 1955-89. Can. Wildl. Serv. Prog. Notes 186. 9pp.

- 1969. High nest density and hatching success of ducks on south Dakota CAP land. Trans. North Am. Wildl. Nat. Resour. Conf. 34:218228.

$\longrightarrow$, AND H. A. KANTRUD. 1974. Upland duck nesting related to land use and predator reduction. J. Wildl. Manage. 38:257-265.

- AND J. T. LOKEMOEN. 1976. Duck nesting in fields of undisturbed grass-legume cover. J. Wildl. Manage. 40:39-49.

$\longrightarrow$, AND — 1980. High duck nesting success in a predator-reduced environment. J. Wildl. Manage. 44:428-437.

Dzubin, A., AND G. B. Gollop. 1972. Aspects of mallard breeding ecology in Canadian parkland and grassland. Pages 113-152 in Population ecology of migratory birds. U.S. Fish Wildl. Serv. Res. Rep. 2.

Freund, R. J., R. C. Littell, and P. C. Spector. 1986. SAS system for linear models. SAS Inst. Inc., Cary, N.C. $211 \mathrm{pp}$.

FurNiss, O. C. 1938. The 1937 waterfowl season in the Prince Albert district, central Saskatchewan. Wilson Bull. 50:17-27.

Green, R. E. 1989. Transformation of crude proportions of nests that are successful for comparison with Mayfield estimates of nest success. Ibis 131:305-306.

GREENWOOD, R. J. 1986. Influence of striped skunk removal on upland duck nest success in North Dakota. Wildl. Soc. Bull. 14:6-11.

-, P. M. ARnold, AND B. G. MCGuire. 1990. Protecting duck nests from mammalian predators with fences, traps, and a toxicant. Wildl. Soc. Bull. 18:75-82.

Hammond, M. C., AND W. R. Forward. 1956. Experiments on causes of duck nest predation. J. Wildl. Manage. 20:243-247.

Hawkins, A. S. 1949. Waterfowl breeding ground survey in Manitoba-1949. Pages 53-68 in Waterfowl populations and breeding conditionssummer 1949. U.S. Fish Wildl. Serv. Spec. Sci. Rep. Wildl. 2.

1950. Waterfowl breeding ground survey in Manitoba-1950. Pages 41-48 in Waterfowl populations and breeding conditions-summer 1950. U.S. Fish and Wildl. Serv. Spec. Sci. Rep. Wildl. 8.

Hestbeck, J. B., A. Dzubin, J. B. Gollop, and J. D. NiCHOLS. 1989. Mallard survival from local to immature stage in southwestern Saskatchewan. J. Wildl. Manage. 53:428-431.

Higgins, K. F., AND W. T. BARKER. 1982. Changes in vegetation structure in seeded nesting cover in the Prairie Pothole Region. U.S. Fish and Wildl. Serv. Spec. Sci. Rep. Wildl. 242. 26pp.

$\longrightarrow$, L. M. KIRSCH, AND I. J. Ball. 1969. A cable-chain device for locating duck nests. J. Wildl. Manage. 33:1009-1011.

—_ - T. A. KletT, AND H. W. Miller. 1992. Waterfowl production on the Woodworth station in south central North Dakota, 1965-1981. U.S. Fish and Wildl. Serv. Resour. Publ. 180. $79 \mathrm{pp}$.

HILL, D. A. 1984. Population regulation in the mal- lard (Anas platyrhynchos). J. Anim. Ecol. 53. 191-202.

Hines, J. E., AND G. J. Mitchell. 1983. Gadwall nest site selection and nesting success. J. Wildl. Manage. 47:1063-1071.

Howard, J. G., R. S. Pospichal, AND D. ReID. 1954. Waterfowl breeding ground studies on the Elkhorn area of southwestern Manitoba. Pages 8693 in Waterfowl populations and breeding conditions-summer 1953. U.S. Fish and Wildl. Serv., Spec. Sci. Rep. Wildl. 25.

JOHNSON, D. H. 1991. Further comments on estimating nest success. Ibis 133:205-208.

$\longrightarrow$, J. D. NiChols, M. J. CONROY, AND L. M. CowARDIN. 1988b. Some considerations in modelling the mallard life cycle. Pages 9-20 in M. W. Weller, ed. Waterfowl in winter. Univ. Minnesota Press, Minneapolis. , AND A. B. SARGEANT. 1977. Impact of red fox predation on the sex ratio of prairie mallards. U.S. Fish and Wildl. Serv. Wildl. Res. Rep. 6. 56 pp.

, AND R. J. GREenwOOD. 1989. Importance of individual species of predators on nesting success of ducks in the Canadian Prairie Pothole Region. Can. J. Zool. 67:291-297.

JoHnSON, M. A., T. C. HINZ, AND T. L. KUCK. $1988 a$. Duck nest success and predators in North Dakota, South Dakota, and Montana. The Central Flyway study. Proc. Great Plains Wildl. Damage Control Workshop 8:125-133.

KAISER, P. H. 1976. Habitat preferences of upland nesting waterfowl in southeastern South Dakota. M.S. Thesis, Univ. Missouri, Columbia. 108pp.

KaLMBACH, E. R. 1938. A comparative study of nesting waterfowl on the lower Souris Refuge: 1936-1937. Trans. North Am. Wildl. Conf. 3:610 623.

1939. Nesting success: its significance in waterfowl reproduction. Trans. North Am. Wildl. Conf. 4:591-604.

KIEL, W. H. 1951. Waterfowl breeding population and production in the Newdale-Erickson district of Manitoba-1951. Pages 50-59 in Waterfowl populations and breeding conditions-summer 1951. U.S. Fish and Wildl. Serv. Spec. Sci. Rep. Wildl. 13.

_. 1953. Waterfowl breeding population and production in the Newdale-Erickson district of Manitoba-1952. Pages 66-70 in Waterfowl populations and breeding conditions-summer 1952. U.S. Fish and Wildl. Serv. Spec. Sci. Rep. Wildl. 21.

1954. Waterfowl breeding population and production in the Newdale-Erickson district of Manitoba-1953. Pages 81-85 in Waterfowl populations and breeding conditions-Summer 1953. U.S. Fish and Wildl. Serv. Spec. Sci. Rep. Wildl. 25.

Klett, A. T., T. L. Shaffer, AND D. H. Johnson. 1988. Duck nest success in the Prairie Pothole Region. J. Wildl. Manage. 52:431-440.

Lokemoen, J. T., H. A. Doty, D. E. Sharp, and J. E. NEAville. 1982. Electric fences to reduce mammalian predation on waterfowl nests. Wildl. Soc. Bull. 10:318-323.

MACNAB, J. 1983. Wildlife management as scien- 
tific experimentation. Wildl. Soc. Bull. 11:397401.

MAyfiELD, H. F. 1961. Nesting success calculated from exposure. Wilson Bull. 73:255-261.

-. 1975. Suggestions for calculating nest success. Wilson Bull. 87:456-466.

MilleR, H. W. 1971. Relationships of duck nesting success to land use in North and South Dakota. Int. Union Game Biol. 10:133-141.

$\longrightarrow$, AND D. H. JOHNSON. 1978. Interpreting the results of nesting studies. J. Wildl. Manage. 42:471-476.

MILONSKI, M. 1958. The significance of farmland for waterfowl nesting and techniques for reducing losses due to agricultural practices. Trans. North Am. Wildl. Conf. 23:215-227.

Nelson, H. K., AND H. F. Duebbert. 1973. New concepts regarding the production of waterfowl and other game birds in areas of diversified agriculture. Int. Union Game Biol. 11:385-394.

NudDS, T. D., AND R. G. Clark. 1992. Landscape ecology, adaptive resource management and the North American waterfowl management plan. Pages 180-190 in G. L. Holroyd, H. L. Dickson, M. Regnier, and H. C. Smith, eds. Proc. third prairie conservation and endangered species workshop. Nat. Hist. Occas. Pap. 19, Prov. Mus. Alberta, Edmonton.

OEtTING, R. B., AND C. C. Dixon. 1975. Waterfowl nest densities and success at Oak Hammock Marsh, Manitoba. Wildl. Soc. Bull. 3:166-171.

ORTHMEYeR, D. L., AND I. J. BALl. 1990. Survival of mallard broods on Benton Lake National Wildlife Refuge in northcentral Montana. J. Wildl. Manage. 54:62-66.

Page, R. D., AND J. F. CASSEl. 1971. Waterfowl nesting on a railroad right-of-way in North $\mathrm{Da}$ kota. J. Wildl. Manage. 35:544-549.

ReEves, H., M. Lundy, AND F. KRELler. 1956. Waterfowl breeding ground survey-success study area, Saskatchewan, 1955. Pages 54-62 in Waterfowl populations and breeding conditionssummer 1955. U.S. Fish and Wildl. Serv. Spec. Sci. Rep. Wildl. 30.

Rotella, J. J., and J. T. Ratti. 1992. Mallard brood survival and wetland habitat conditions in southwestern Manitoba. J. Wildl. Manage. 56: 499-507.

- R. J. Greenwood, M. A. Sovada, And T. L. SHAFFER. 1993. Distribution and abundance of predators that affect duck production-the Prairie Pothole Region. U.S. Fish and Wildl. Serv. Res. Publ. 194. 96pp.

$\longrightarrow$, AND D. G. Raveling. 1992. Mortality during the breeding season. Pages 396-422 in B. D. J. Batt, A. D. Afton, M. G. Anderson, C. D. Ankney, D. H. Johnson, J. A. Kadlec, and G. L. $\mathrm{Krapu}$, eds. The ecology and management of breeding waterfowl. Univ. Minnesota Press, Minneapolis.

SAS INSTITUTE INC. 1985. SAS/STAT guide for per- sonal computers. Version 6. SAS Inst. Inc., Cary, N.C. 378pp.

Simpson, S. G. 1988. Duck nest success on South Dakota game production areas. Proc. Great Plains Wildl. Damage Control Workshop 8:140-145.

SMITH, A. G. 1954. Waterfowl breeding ground surveys of special study areas in Alberta-1953. Pages 30-42 in Waterfowl populations and breeding conditions-summer 1953. U.S. Fish and Wildl. Serv. Spec. Sci. Rep. Wildl. 25.

—_. 1956. Waterfowl breeding ground surveys of special study areas in Alberta-1955. Pages 3344 in Waterfowl populations and breeding conditions-summer 1955. U.S. Fish and Wildl. Serv. Spec. Sci. Rep. Wildl. 30.

STOUDT, J. H. 1953. Waterfowl breeding ground survey of Redvers area, Saskatchewan. Pages 5260 in Waterfowl populations and breeding conditions-summer 1952. U.S. Fish Wildl. Serv. Spec. Sci. Rep. Wildl. 21.

- 1971. Ecological factors affecting waterfowl production in Saskatchewan parklands. U.S. Fish and Wildl. Serv. Resour. Publ. 99. 58pp. , AND R. J. Buller. 1954. Waterfowl breeding ground survey of Redvers area, Saskatchewan. Pages 55-64 in Waterfowl populations and breeding conditions-summer 1953. U.S. Fish and Wildl. Serv. Spec. Sci. Rep. Wildl. 25.

, AND M. STINNETT. 1955. Waterfowl breeding ground survey of Redvers area, Saskatchewan 1952-1954. Pages 56-65 in Waterfowl populations and breeding conditions-summer 1954. U.S. Fish and Wildl. Serv. Spec. Sci. Rep. Wildl. 27. -, AND B. A. YEAGER. 1956. Waterfowl breeding ground survey of Redvers area, Saskatchewan 1952-1955. Pages 63-72 in Waterfowl populations and breeding conditions-summer 1955. U.S. Fish and Wildl. Serv. Spec. Sci. Rep. Wildl. 30.

Sugden, L. G., AND G. W. Beyersbergen. 1985. Prediction of duck nest survival in conventional and zero-tilled stubble fields. Can. Wildl. Serv. Prog. Notes 156. 6pp.

Talent, L. G., R. L. JaRVis, AND G. L. Krapu. 1983. Survival of mallard broods in south central North Dakota. Condor 85:74-78.

U.S. Fish and Wildlife SERvice and CAN. WildLIFE SERVICE. 1986. North American waterfowl management plan. U.S. Fish and Wildl. Serv., Washington, D.C., and Can. Wildl. Serv., Ottawa, Ont. 19pp.

Weller, M. W. 1979. Density and habitat relationships of blue-winged teal nesting in northwestern Iowa. J. Wildl. Manage. 43:367-374.

Williams, G. D. V., and G. W. Robertson. 1965. Estimating most probable prairie wheat production from precipitation data. Can. J. Plant Sci. 45:34-47.

Received 2 June 1993.

Accepted 29 June 1995.

Associate Editor: Samuel. 
Appendix A. Published and unpublished sources of nest success data for 5 species of upland-nesting ducks in the Prairie Pothole Region, 1935-92. Unpooled refers to nest success estimates that were kept separate for each species at each site in each year. Pooled refers to nest success estimates pooled for all species present at each site each year. Note that the pooled dataset may include more species and more nests. The number of estimates of nest success $(n)$ and the number of nests on which each study was based are given. Data from islands or predator control sites were not included. NWA = national wildlife area, $\mathrm{WMD}=$ wetland management district, $\mathrm{WPA}=$ waterfowl production area.

\begin{tabular}{|c|c|c|c|c|c|c|c|}
\hline \multirow[b]{2}{*}{ Reference } & \multirow[b]{2}{*}{$\begin{array}{c}\text { Year(s) } \\
\text { of study }\end{array}$} & \multirow[b]{2}{*}{ Study site } & \multicolumn{2}{|c|}{ Unpooled } & \multicolumn{2}{|c|}{ Pooled } & \multirow[b]{2}{*}{$\begin{array}{c}\text { Estimator } \\
\text { used }\end{array}$} \\
\hline & & & $n$ & $\begin{array}{c}\text { No. } \\
\text { nests }\end{array}$ & $n$ & $\begin{array}{c}\text { No. } \\
\text { nests }\end{array}$ & \\
\hline \multirow[t]{2}{*}{ Adams, G. D., unpubl. } & $1981-82$ & Thickwood Hills, SK & 3 & 54 & 2 & 63 & Mayfield \\
\hline & $1989-90$ & & 2 & 49 & 2 & 49 & Mayfield \\
\hline \multirow[t]{2}{*}{ Clark et al. 1991} & $1980-81$ & St. Denis, NWA, Sask. & 6 & 153 & 2 & 153 & Mayfield \\
\hline & $1983-85$ & & 11 & 281 & 3 & 281 & Mayfield \\
\hline \multirow[t]{2}{*}{ Clark, R. G., unpubl. data } & 1990 & Elstow, Sask. & & & 1 & 32 & Mayfield \\
\hline & 1990 & Yorkton, Sask. & 3 & 39 & 1 & 78 & Green \\
\hline Cowardin et al. 1985 & $1977-80$ & N.D. & 4 & 129 & 4 & 129 & Mayfield \\
\hline Duebbert and Kantrud 1974 & 1971 & S.D. (2 sites) & & & 2 & 245 & Green \\
\hline $\begin{array}{l}\text { Duebbert and Lokemoen } \\
1976\end{array}$ & $1971-73$ & Edmunds County, S.D. & 12 & 544 & 3 & 569 & Green \\
\hline $\begin{array}{l}\text { Duebbert and Lokemoen } \\
1980\end{array}$ & $1973-74$ & Hosmer, S.D. & 5 & 167 & 2 & 180 & Green \\
\hline \multirow[t]{2}{*}{ Dzubin and Gollop 1972} & $1952-55$ & Roseneath, Manit. & 4 & 213 & 4 & 213 & Green \\
\hline & $1956-58$ & Kindersley, Sask. & 3 & 611 & 3 & 611 & Green \\
\hline Furniss 1938 & $\begin{array}{l}1935 \\
1937\end{array}$ & Prince Albert, Sask. & 2 & 33 & 2 & 33 & Green \\
\hline \multirow[t]{6}{*}{ Greenwood 1986} & 1979 & Gaier WPA, N.D. & & & 1 & 204 & Mayfield \\
\hline & 1979 & Haglund WPA, N.D. & & & 1 & 68 & Mayfield \\
\hline & 1980 & $\begin{array}{l}\text { Crystal Springs WPA, } \\
\text { N.D. }\end{array}$ & & & 1 & 73 & Mayfield \\
\hline & 1980 & Haglund, N.D. & & & 1 & 71 & Mayfield \\
\hline & $1980-81$ & Ackerson, WPA, N.D. & & & 2 & 110 & Mayfield \\
\hline & 1981 & $\begin{array}{l}\text { Jamestown College } \\
\text { WPA, N.D. }\end{array}$ & & & 1 & 91 & Mayfield \\
\hline \multirow[t]{4}{*}{ Greenwood et al. 1990} & $1982-84$ & Ackerson WPA, N.D. & & & 3 & 96 & Mayfield \\
\hline & $1982-85$ & Gaier WPA, N.D. & & & 4 & 87 & Mayfield \\
\hline & $1983-84$ & $\begin{array}{l}\text { Jamestown College } \\
\text { WPA, N.D. }\end{array}$ & & & 2 & 35 & Mayfield \\
\hline & 1984 & Hertel WPA, N.D. & & & 1 & 13 & Mayfield \\
\hline \multirow{17}{*}{$\begin{array}{l}\text { Greenwood, R. J., USFWS, } \\
\text { pers. comm. }\end{array}$} & 1982 & Tichfield, Sask. & 5 & 91 & 1 & 91 & Mayfield \\
\hline & $1982-85$ & Hanley, Sask. & 9 & 212 & 4 & 212 & Mayfield \\
\hline & $1982-85$ & Shamrock, Sask. & 14 & 838 & 4 & 884 & Mayfield \\
\hline & 1983 & Cartwright, Manit. & 2 & 32 & 1 & 32 & Mayfield \\
\hline & 1983 & Goodwater, Sask. & 5 & 265 & 1 & 281 & Mayfield \\
\hline & 1983 & Holden, Alta. & 4 & 158 & 1 & 158 & Mayfield \\
\hline & $1983-84$ & Ceylon, Sask. & 9 & 718 & 2 & 774 & Mayfield \\
\hline & $1983-84$ & Hay Lakes, Alta. & 8 & 324 & 2 & 324 & Mayfield \\
\hline & $1983-84$ & Moorepark, Manit. & 8 & 257 & 2 & 257 & Mayfield \\
\hline & $1984-85$ & Craik, Sask. & 3 & 39 & 2 & 39 & Mayfield \\
\hline & $1984-85$ & Denzil, Sask. & 7 & 189 & 2 & 189 & Mayfield \\
\hline & $1984-85$ & Leask, Sask. & 7 & 225 & 2 & 225 & Mayfield \\
\hline & 1984-85 & Penhold, Alta. & 2 & 66 & 2 & 66 & Mayfield \\
\hline & 1985 & Earl Grey, Sask. & 4 & 123 & 1 & 123 & Mayfield \\
\hline & 1984-85 & Inchkeith, Sask. & 4 & 67 & 2 & 67 & Mayfield \\
\hline & 1985 & Gayford, Alta. & 4 & 57 & 1 & 57 & Mayfield \\
\hline & 1985 & Yorkton, Sask. & 3 & 144 & 1 & 156 & Mayfield \\
\hline Hawkins 1949 & 1949 & Southwestern Manit. & 3 & 132 & 1 & 150 & Green \\
\hline Hawkins 1950 & 1950 & Southwestern Manit. & 2 & 51 & 1 & 57 & Green \\
\hline Higgins et al. 1992 & 1966-81 & Woodworth, N.D. & & & 16 & 3,517 & Mayfield \\
\hline Howard et al. 1954 & 1953 & Elkhorn Area, Manit. & 1 & 63 & 1 & 89 & Green \\
\hline \multirow[t]{5}{*}{ Johnson et al. $1988 a$} & 1983 & Streeter, N.D. & 4 & 115 & 1 & 124 & Mayfield \\
\hline & 1983 & Sharon, N.D. & 1 & 42 & 1 & 56 & Mayfield \\
\hline & 1983 & Plaza, N.D. & 5 & 193 & 1 & 198 & Mayfield \\
\hline & 1983 & Madison, S.D. & 2 & 68 & 1 & 78 & Mayfield \\
\hline & 1983 & Parkston, S.D. & 2 & 63 & 1 & 73 & Mayfield \\
\hline
\end{tabular}


Appendix A. Continued.

\begin{tabular}{|c|c|c|c|c|c|c|c|}
\hline \multirow[b]{2}{*}{ Reference } & \multirow[b]{2}{*}{$\begin{array}{c}\text { Year(s) } \\
\text { of study }\end{array}$} & \multirow[b]{2}{*}{ Study site } & \multicolumn{2}{|c|}{ Unpooled } & \multicolumn{2}{|c|}{ Pooled } & \multirow[b]{2}{*}{$\begin{array}{c}\text { Estimator } \\
\text { used }\end{array}$} \\
\hline & & & $n$ & $\begin{array}{l}\text { No. } \\
\text { nests }\end{array}$ & $n$ & $\begin{array}{l}\text { No. } \\
\text { nests }\end{array}$ & \\
\hline \multirow[t]{2}{*}{ Kaiser 1976} & 1974 & Madison WMD, S.D. & 1 & 61 & 1 & 81 & Green \\
\hline & 1974 & Lake Andes WMD, S.D. & 1 & 137 & 1 & 167 & Green \\
\hline Kalmbach 1938 & 1936 & $\begin{array}{l}\text { Lower Souris Refuge, } \\
\text { N.D. }\end{array}$ & 5 & 303 & 1 & 326 & Green \\
\hline Kiel 1951 & $1949-51$ & $\begin{array}{l}\text { Newdale-Erickson Area, } \\
\text { Manit. }\end{array}$ & & & 3 & 101 & Green \\
\hline Kiel 1953 & 1952 & Newdale-Erickson & & & 1 & 48 & Green \\
\hline Kiel 1954 & 1953 & Newdale-Erickson & 3 & 238 & 1 & 238 & Green \\
\hline Lokemoen et al. 1982 & $1978-80$ & Gaub WPA, N.D. & & & 3 & 64 & Mayfield \\
\hline Oetting and Dixon 1975 & 1974 & $\begin{array}{l}\text { Oak Hammock Marsh, } \\
\text { Manit. }\end{array}$ & 4 & 223 & 1 & 224 & Green \\
\hline Page and Cassel 1971 & 1969 & Railway ROW, N.D. & & & 1 & 80 & Green \\
\hline Reeves et al. 1956 & 1955 & Success, Sask. & 2 & 130 & 1 & 138 & Green \\
\hline Simpson 1988 & 1985 & S.D. (11 sites) & 6 & 132 & 11 & 228 & Mayfield \\
\hline \multirow[t]{2}{*}{ Smith 1954} & 1953 & Lousana, Alta. & 2 & 24 & 1 & 30 & Green \\
\hline & & Vermillion, Alta. & 1 & 50 & 1 & 61 & Green \\
\hline \multirow[t]{2}{*}{ Smith 1956} & 1955 & Lousana, Alta. & 3 & 65 & 1 & 73 & Green \\
\hline & & Vermillion, Alta. & 1 & 35 & 1 & 49 & Green \\
\hline Stoudt 1953 & 1952 & Redvers, Sask. & 2 & 94 & 1 & 109 & Green \\
\hline \multirow[t]{2}{*}{ Stoudt 1971} & $1956-60$ & Redvers, Sask. & 12 & 1,324 & 5 & 1,347 & Green \\
\hline & 1964 & & 2 & 24 & 1 & 26 & Green \\
\hline Stoudt and Buller 1954 & 1953 & Redvers, Sask. & 3 & 287 & 1 & 299 & Green \\
\hline Stoudt and Stinnett 1955 & 1954 & Redvers, Sask. & 4 & 334 & 1 & 353 & Green \\
\hline Stoudt and Yeager 1956 & 1955 & Redvers, Sask. & 3 & 294 & 1 & 313 & Green \\
\hline $\begin{array}{l}\text { Taylor, P. S., CWS, pers. } \\
\text { comm. }\end{array}$ & 1992 & Last Mt. NWA, Sask. & & & 1 & 389 & Green \\
\hline $\begin{array}{l}\text { Wright, M., DU (Can.), } \\
\text { unpubl. data }\end{array}$ & 1972 & Colonsay, Sask. & 4 & 86 & 1 & 91 & Green \\
\hline Total & & & 232 & 10,646 & 143 & 163,513 & \\
\hline
\end{tabular}

